\title{
A new era of treatment for patients with haemophilia A?
}

\author{
Robert Klamroth
}

Zentrum für Hämophilie und Hämostaseologie, Vivantes - Netzwerk für Gesundheit, Berlin, Germany

\author{
Keywords \\ haemophilia $A$, inhibitor, prophylaxis, bispeci- \\ fic antibody
}

\section{Summary}

Treatment and prevention of bleeding episodes in patients with severe haemophilia $A$ require frequent intravenous injection of factor VIII. Inhibitory antibodies against factor VIII occur in approximately $30 \%$ of these patients during the first exposure days and immune tolerance induction to eradicate the inhibitor is challenging. Prevention of bleeds in patients with haemophilia $A$ and inhibitors is less effective and there is ongoing research for alternative treatment options. A promising approach in 2016 is the development of emicizumab (ACE910), a bi-specific lgG antibody to factor IXa and factor $X$, that mimics the cofactor function of factor VIII. Due to the different structure of this antibody it cannot be neutralized by factor VIII inhibitors and has the possibility to achieve haemostasis in patients with severe haemophilia $A$ with and without inhibitors. First studies in healthy volunteers and in patients showed a shortened activated partial thromboplastin time and increased peak height of thrombin gen-

Korrespondenzadresse

Dr. med. Robert Klamroth

Zentrum für Hämophilie und Hämostaseologie

Vivantes - Netzwerk für Gesundheit

Landsberger Alle 49

10249 Berlin, Germany

Tel.: +49 30 130231623; Fax: +4930130231313

E-mail: robert.klamroth@vivantes.de eration in a dose-dependent manner. The halflife of the drug was 4 to 5 weeks. There were no clinical signs of thrombosis and no laboratory abnormalities indicating hypercoagulability. In a first study with 18 patients with severe haemophilia $A$ with and without inhibitors a remarkable reduction in the annualised bleeding rate occurred. Safety of the drug has to be proven in ongoing research. Mimicking the cofactor activity of factor VIII by a bispecific antibody for the treatment of severe haemophilia A is so far safe and seems to be effective and is one highlight in haemostasis 2016.

\section{Schlüsselwörter}

Hämophilie A, Inhibitor, Prophylaxe, bispezifischer Antikörper

\section{Zusammenfassung}

Zur Behandlung und Prophylaxe von Blutungen bei Patienten mit schwerer Hämophilie A sind regelmäßige intravenöse Injektionen des fehlenden Faktors VIII notwendig. Inhibierende Antikörper ((Hemmkörper) gegen Faktor VIII treten bei etwa $30 \%$ der Patienten mit schwerer Hämophilie A während der ersten

Eine neue Ära in der Behandlung von Patienten mit Hämophilie A?

Hämostaseologie 2017; 37: 216-218 https://doi.org/10.5482/HAMO-16-07-0028 received: July 24, 2016

accepted in revised form: November 4, 2016 epub ahead of print: November 25, 2016
Expositionstage auf und machen eine aufwändige Immuntoleranztherapie notwendig. Die Prophylaxe von Blutungen bei diesen Patienten ist weniger effektiv als die Prophylaxe mit Faktor VIII bei Patienten ohne Hemmkörper, sodass nach alternativen Behandlungsmethoden gesucht wird. Ein vielversprechender Ansatz im Jahr 2016 ist die Entwicklung von Emicizumab (ACE910), einem bispezifischen lgG-Antikörper gegen die Faktoren IXa und $\mathrm{X}$, der die Cofaktor-Aktivität des Faktors VIII imitiert. Aufgrund der anderen Struktur dieses Antikörpers wird er nicht durch den Faktor-VIII-Hemmkörper in seiner Funktion beeinträchtigt und kann zu einer suffizienten Hämostase bei Patienten mit Hämophilie A mit und ohne Hemmkörper führen. Erste Studien an gesunden Freiwilligen und Patienten zeigten eine dosisabhängige Korrektur der aPTT und eine verbesserte Thrombingenerierung. Die Halbwertszeit betrug 4-5 Wochen und es zeigten sich weder klinische Zeichen einer Thrombose noch auffällige Laborwerte im Hinblick auf eine Hyperkoagulabilität. Die erste Studie mit $18 \mathrm{~Pa}$ tienten mit schwerer Hämophilie A mit und ohne Hemmkörper zeigte eine deutliche Reduktion der annualisierten Blutungsrate. Die Sicherheit des Antikörpers muss in weiteren Studien demonstriert werden. Die Imitation der Faktor-VIII-Cofaktor-Aktivität mit dem bispezifischen Antikörper Emicizumab (ACE910) scheint bisher sicher und effektiv zu sein und ist ein Highlight in der Hämostase im Jahr 2016.
Haemophilia A is an X-linked bleeding disorder leading to the complete absence or decrease of clotting factor VIII. Treatment and prevention of bleeding episodes require intravenous injection of clotting factor VIII. Due to the half-life of factor VIII (8-12 hours), patients with severe haemophilia A have to inject factor VIII concentrates intravenously 3 times a week or every other day to prevent bleeding. This leads to more than 150 intravenous injections per year.

The most serious complication of replacement therapy to factor VIII now- adays is the development of inhibitory antibodies against factor VIII. These inhibitors occur in approximately $30 \%$ of patients with severe haemophilia A during the first 20 exposure days with factor VIII. In patients with high titer inhibitors $(>5 \mathrm{BU})$ treatment with factor VIII is no 
longer effective due to the rapid inactivation of the infused factor VIII and bypassing agents are necessary. Two bypassing agents (recombinant factor VIIa and activated prothrombin complex) are available for treatment of acute bleeds in these patients. Unfortunately, treatment and prevention of bleeds in patients with haemophilia A and inhibitors are less effective than the replacement therapy with factor VIII in patients without inhibitors. Both products have limitations concerning efficacy to treat and prevent bleeds. So the major goal is to eradicate the inhibitor in these patients by achieving immune tolerance.

Immune tolerance induction requires high doses of factor VIII and imposes a high burden on the patient with the necessity of up to twice daily intravenous injections, which usually require a port system.

\section{Bi-specific antibodies - a promising new approach}

There is ongoing research for alternative treatment options to treat and prevent bleeds in patients with haemophilia A and inhibitors without the burden of multiple intravenous injections.

One of the most promising approaches in 2016 - combining the prophylactic treatment of patients with haemophilia $\mathrm{A}$ and inhibitors with the possibility of subcutaneous injections - is the development of emicizumab (ACE910), a bi-specific IgG antibody to factor IXa and factor X that mimics the cofactor activity of factor VIII. Factor VIII is a cofactor in the coagulation system which promotes interaction between activated factor IX and factor X and allows the generation of activated factor $\mathrm{X}$ ( Fig. 1). Due to the different structure of this antibody it cannot be neutralized by factor VIII inhibitors and has the potential to achieve haemostasis in patients with haemophilia A with and without inhibitors (1).

A study in a non-human primate model of acquired haemophilia A showed that a single bolus of emicizumab (ACE910) resulted in a haemostatic activity and showed a long half-life (3 weeks) and a high subcu- taneous bioavailability (nearly $100 \%$ ). In a long-term primate model of acquired haemophilia A, multiple weekly subcutaneous doses of emicizumab (ACE910) successfully prevented bleeding in these animals (2).

The first-in-human study (3) was conducted in healthy male adults (40 Japanese and 24 Caucasian men) receiving a single subcutaneous injection of emicizumab (ACE910) up to $1 \mathrm{mg} / \mathrm{kg}$ bodyweight. This dose is assumed to generate the same amount of thrombin as $0.10 \mathrm{IU} / \mathrm{ml}$ factor VIII coagulant activity. Emicizumab (ACE910) showed a linear PK profile in these healthy volunteers without affecting the concentration of factor IX and factor X. Emicizumab (ACE910) had a half-life of 4-5 weeks.

In ex vivo factor VIII neutralized plasma of the participants, emicizumab (ACE910) shortened activated partial thromboplastin time and increased peak height of thrombin generation in a dose-dependent manner. There were no clinical signs of thrombosis and no laboratory abnormalities indicating hypercoagulability (like elevated D-Dimer) in these healthy volunteers with a normal coagulation system.

Two of the participants receiving emicizumab (ACE910) were positive for antiACE910 antibodies (anti-drug antibodies).

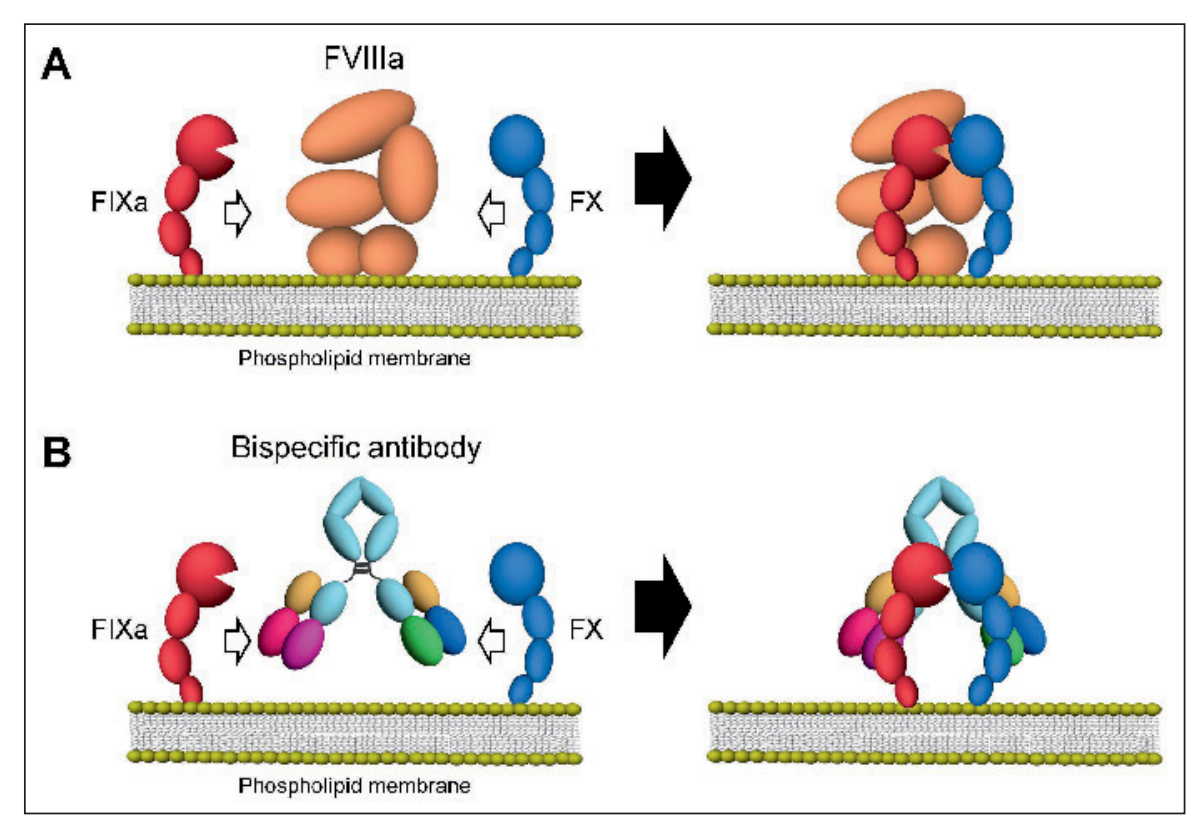

Fig. 1 Schematic illustration of the action of activated factor VIII as a cofactor in coagulation (A) and emicizumab (ACE910), a bispecific antibody against factor IXa and factor X (B) (1). drug antibodies both before and after emicizumab (ACE910) administration, but the other one became anti-drug antibody positive after receiving emicizumab (ACE910). In this subject the elimination half-life of emicizumab (ACE910) was reduced indicating that this was maybe a potentially functional anti-drug antibody.

The first study in patients with haemophilia A enrolled in a 12-weeks openlabel non-randomised dose escalation trial (4) 18 Japanese patients with severe haemophilia A with and without inhibitors. In this study emicizumab (ACE910) was given subcutaneously at a dose of $0.3,1.0$ or $3.0 \mathrm{mg} / \mathrm{kg}$ bodyweight weekly (cohorts 1,2 and 3, respectively). These doses resulted in plasma emicizumab (ACE910) trough levels of 10,30 and $90 \mu \mathrm{g} / \mathrm{ml}$, respectively. These levels seem to have an equivalent haemostatic activity like approximately 3, 9 and $27 \mathrm{IU} / \mathrm{ml}$ factor VIII coagulant activity.

No serious adverse events and no clinically relevant coagulation abnormalities occurred. Plasma concentrations of emicizumab (ACE910) increased in a dosedependent manner and there was a measurable effect by a shortened activated partial-thromboplastin time throughout the study.
One of them was tested positive for anti-

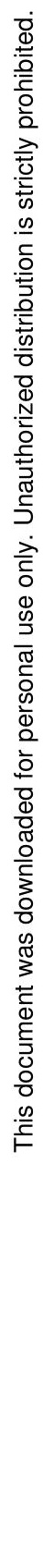


The median annualised bleeding rates in cohorts 1,2 , and 3 decreased from 32.5 to $4.4,18.3$ to 0.0 , and 15.2 to 0.0 . Eight out of 11 patients with factor VIII inhibitors (73\%) experienced no bleeding event and 5 of $7 \mathrm{pa}-$ tients without factor VIII inhibitors (71\%). All bleeding events in the study were treated successfully with the replacement of factor VIII. In this study no patient developed antibodies against emicizumab (ACE910).

\section{Conclusion}

Analysing the mentioned publications, emicizumab (ACE910) has the potential to change the treatment of patients with severe haemophilia A fundamentally from regular intravenous injections to once weekly subcutaneous injections. Taking into account the long half-life of the antibody even subcutaneous injections every 4 weeks might be possible for the prevention of bleeds. Especially patients with hae- mophilia A and inhibitors will take advantage of this new therapy due to the limitations of prophylactic treatment with bypassing agents.

The main question will be the immunogenicity of emicizumab (ACE910) itself. The number of patients who might develop anti-drug antibodies with impact on the product half-life is still an open question in long-term treatment. Up to know no concerns of a thrombotic risk of emicizumab (ACE910) have been raised in the published studies. Safety is paramount in the treatment of patients with haemophilia A, and the current treatment options with factor VIII concentrates have a long track of safety. Emicizumab (ACE910) will have to prove safety in a reasonable number of patients in the future.

Mimicking the cofactor activity of factor VIII by a bispecific antibody is a simple and so far convincing idea and therefore a highlight in haemostasis 2016.

\section{Conflict of interest}

The author declares that he received speaker and consultant fees and research grants from Baxalta/Shire, Bayer, BiogenIdec, Biotest, CSL Behring, Grifols, LEO, NovoNordisk, Octapharma, Pfizer, SOBI.

\section{References}

1. Sampei Z, Igawa $\mathrm{T}$, Soeda $\mathrm{T}$ et al. Identification and multidimensional optimization of an asymmetric bispecific IgG antibody mimicking the function of factor VIII cofactor activity. PLoS One 2013; 8(2):e57479.

2. Muto A, Yoshihashi K, Takeda M et al. Anti-factor IXa/X bispecific antibody ACE910 prevents joint bleeds in a long-term primate model of acquired hemophilia A. Blood 2014; 124(20): 3165-3171.

3. Uchida N, Sambe T, Yoneyama K et al. A first-inhuman phase 1 study of ACE910, a novel factor VIII-mimetic bispecific antibody, in healthy subjects. Blood 2016; 127(13): 1633-1641.

4. Shima M, Hanabusa H, Taki M et al. Factor VIIIMimetic Function of Humanized Bispecific Antibody in Hemophilia A. N Engl J Med 2016; 374(21): 2044-2053.

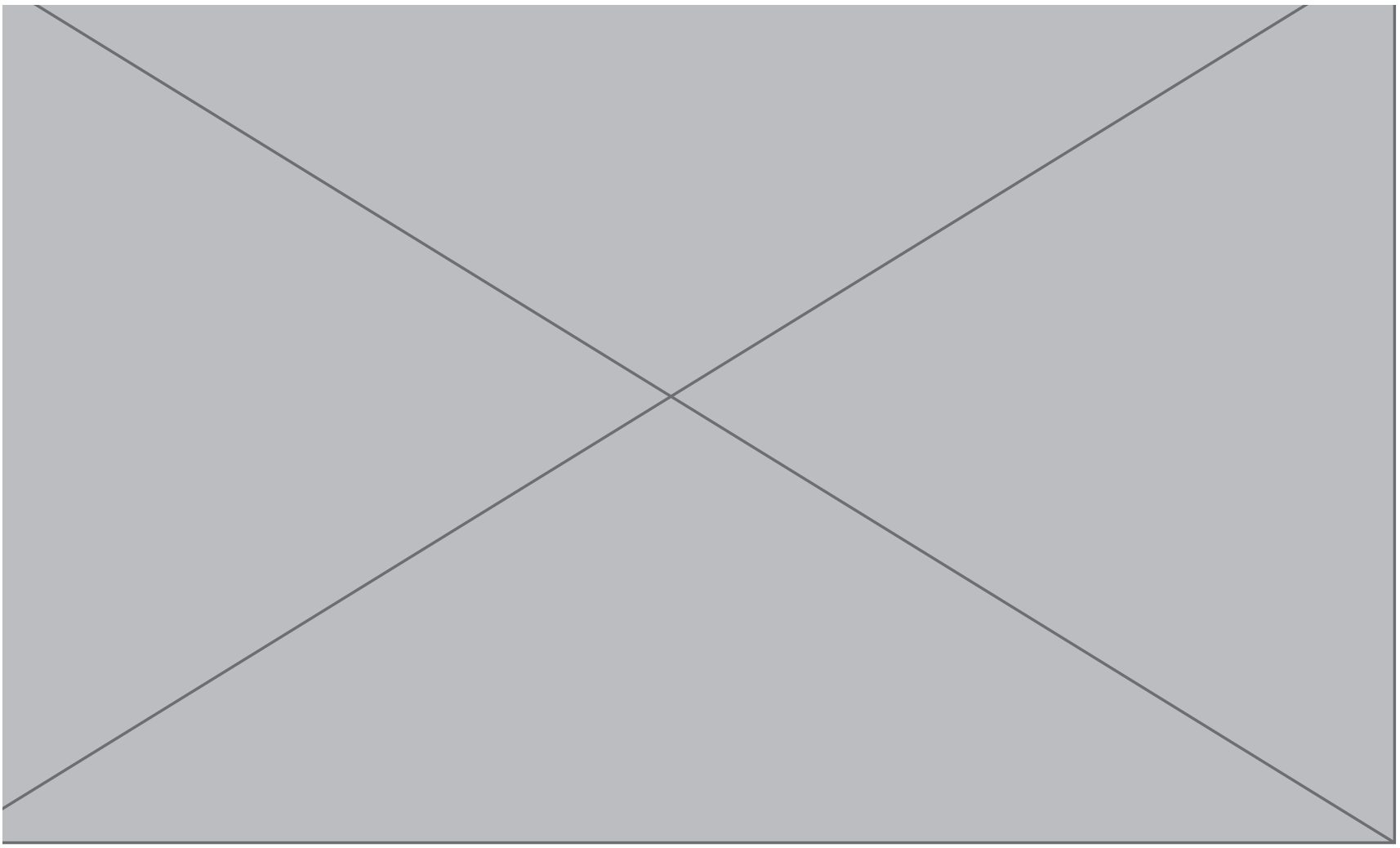

